\title{
ОЦІНКА ФУНКЦІОНАЛЬНОГО СТАНУ ОРГАНІЗМУ СТУДЕНТІВ-МЕДИКІВ КОНОТОПСЬКОГО МЕДИЧНОГО УЧИЛИЩА ЗІ СКОЛІОЗОМ I-II СТУПЕНІВ ПІД ЧАС ЗАНЯТЬ ЛІКУВАЛЬНОЮ ФІЗИЧНОЮ КУЛЬТУРОЮ ТА ПРОВЕДЕННЯ МАСАЖУ
}

\author{
Н. В. Тимошенко
}

Конотопське медичне училище

У статті проаналізовано літературні джерела 3 питань етіології, патогенезу та методів лікування сколіозу I-II ступенів. Досліджено ефективність застосування нових методик лікувальної фізкультури функціонального відновлення хребта та масажу, їх вплив на рівень фізичної працездатності й показники фізичного стану при сколіозі I-II ступенів у студентів Конотопського медичного училища.

\section{PHYSICAL ASSESSMENT OF STUDENTS IN KONOTOP MEDICAL COLLEGE WITH I-II DEGREE SCOLIOSIS DURING PHYSICAL THERAPY AND MASSAGE CLASSES}

\section{N. V. Tymoshenko}

\section{Konotop Medical College}

The article presents a literature rewiew of etiology, pathogenesis and treatment of I-II degree scoliosis. It was investigated the efficiency of new methods of physical therapy and functional recovery of spine and massage as well as their impact on physical activities and physical health indexes in students of Konotop Medical Colledge with I-II degree scoliosis.

Вступ. Сколіоз - це широке поняття, що включає морфофункціональні зміни організму людини, які виникають внаслідок викривлення хребта і проявляється змінами діяльності дихальної, серцево-судинної, нервової систем, опорно-рухового апарату тощо. Сколіоз $є$ небезпечною хворобою, адже порушення рівноваги, особливо з боку «основної опори» людського організму, має тяжкі наслідки, що значно погіршує якість життя і, як наслідок, здатні досить вагомо зменшувати тривалість життя в цілому. У дітей і підлітків часто розвивається сколіотична хвороба, яка потребує комплексного ортопедичного лікування, оскільки у нелікованих хворих або при пізній діагностиці настає тяжка інвалідність. Дегенеративнодистрофічні захворювання хребта, які виникають у молодому і середньому віці, за статистичними даними, призводять до тривалої тимчасової або й постійної непрацездатності.

Дана проблема постає досить гостро, оскільки поширеність сколіозу серед населення, зокрема дитячого, є досить великою. Вважається, що справжній

(c) Н. В. Тимошенко, 2016 (структуральний) сколіоз розвивається лише у період формування та розвитку скелету. За даними різних авторів, найінтенсивніше сколіоз прогресує протягом перших двох років життя та після 10 років. Це пов'язують з швидким ростом та розвитком кісткової тканини у дані періоди.

Порушення постави спостерігається у дітей вже в ранньому віці (в дитячому садку 80 \% дітей віком 5-6 років мають різні дефекти хребта). У дошкільному віці порушення постави часто має функціональний характер і зумовлюється в основному слабкістю м'язового тонусу і зв'язкового апарату [1, 2].

Статистика численних досліджень із виявлення сколіозу в підлітків свідчить, що ця деформація - одне з найбільш частих захворювань опорно-рухового апарату, яке має тенденцію до прогресування і досягає вищого ступеня до закінчення росту організму $[4,5]$. Тяжкі викривлення хребта і грудної клітки значно впливають на функції внутрішніх органів: зменшують об'єм плевральних порожнин, порушують механіку дихання, що, в свою чергу, погіршує функцію зовнішнього дихання, знижує насичення артеріальної 
крові киснем, змінює характер тканинного дихання, викликає гіпертензію в малому колі кровообігу, гіпертрофію міокарда правої половини серця, розвиток симптомокомплексу легенево-серцевої недостатності. Така велика увага до цієї групи захворювань дозволяє розширити наші знання про причини виникнення і боротьби із хворобами хребта на більш високому рівні. В наш час, розробляючи стратегію боротьби з болями у спині, лікарі часто звертають увагу не тільки на медикаментозне і хірургічне лікування, але і на правильне харчування, фізичну активність і застосування нетрадиційних методів лікування.

Навіть при наявності схильності організму до захворювань хребта їх можна уникнути, якщо розробити навички правильної осанки і виконувати вправи, направлені на гармонійний розвиток опорно-рухового апарату. Одним із головних методів лікування неправильної осанки і захворювань хребта $є$ ліку- вальна фізкультура. Але ніяке лікування не може бути ефективним без усунення причини захворювання, i всі профілактичні заходи необхідно виконувати під час лікування.

Аналіз науково-методичної літератури з питань розвитку, лікування й реабілітації сколіозу свідчить, що основні праці присвячені опису вже відомих фактів і не враховують належною мірою особливості застосування нових методик функціонального відновлення хребта $[6,7]$.

Основна частина. У результаті проведення тестування встановлено, що з 76 обстежених дітей віком 15-16 років різні дефекти постави на початковому рівні мають 58 осіб. 18 осіб були практично здоровими. Результати тестування наведені в тестовій карті.

Виявлені різні типи постави відповідно до соматоскопічних досліджень (табл. 1). 376 дітей тільки 18 мають нормальну поставу $(23,7 \%)$.

таблиця 1. Різні типи постави відповідно до соматоскопічних досліджень

\begin{tabular}{|l|c|c|}
\hline \multicolumn{1}{|c|}{ Тип постави } & Кількість дітей & 23,7 \\
\hline Нормальна постава & 18 & 25,0 \\
\hline Сутула постава & 19 & 9,2 \\
\hline Кругла постава & 7 & 3,9 \\
\hline Плоска постава & 3 & 13,2 \\
\hline Кіфоз & 10 & 17,1 \\
\hline Асиметрична постава & 13 & 7,9 \\
\hline Сколіоз I ступеня & 6 & 0 \\
\hline Сколіоз ІІ ступеня & не виявлено & 0 \\
\hline Сколіоз ІІІ ступеня & не виявлено & 0 \\
\hline Сколіоз ІV ступеня & не виявлено & 100 \\
\hline Всього & 76 & \\
\hline
\end{tabular}

У результаті огляду були отримані такі дані про типи постави.

Дослідження включало три етапи. Перший етап передбачав вивчення й аналіз наукової та науковометодичної літератури з обраної теми. Другий етап включав проведення констатуючого експерименту вивчали фізичну працездатність та фізичний стан студентів групи фізичної реабілітації зі сколіозом I-ІІ ступенів. Головним завданням цього етапу було отримання показників, що характеризують фізичну працездатність і фізичний стан студентів зі сколіозом I-ІІ ступенів (табл. 2).

Другий етап також передбачав розроблення комплексу вправ ЛФК та методики масажу. Третій етап передбачав упровадження програми консервативного лікування. Наростання навантаження відбувалося шляхом збільшення кількості повторів вправ, тривалості занять. Після завершення курсу занять проведе-

таблиця 2. Антропометричні показники фізичного розвитку дітей віком 15-16 років

\begin{tabular}{|c|c|c|c|c|c|c|}
\hline Вік (роки) & Зріст (см) & Сигма & Маса (кг) & Сигма & Грудна клітка (см) & Сигма \\
\hline \multicolumn{7}{|c|}{ хлопці } \\
\hline 15 & 133 & 6 & 30,2 & 3,6 & 65,0 & 3,6 \\
\hline 16 & 137 & 6,4 & 32 & 4,2 & 66,0 & 3,4 \\
\hline \multicolumn{7}{|c|}{ дівчата } \\
\hline 15 & 131,5 & 6,2 & 28,2 & 3,8 & 62,0 & 3,8 \\
\hline 16 & 137,2 & 6,4 & 32,6 & 4,6 & 65,0 & 4,6 \\
\hline
\end{tabular}


но повторне тестування для визначення ефективності занять та проведено порівняльну оцінку результатів дослідження до й після завершення експерименту.

Сколіоз є досить складним і поширеним ортопедичним захворюванням, яке потребує своєчасного й адекватного лікування. Фактором, що визначає клінічну картину сколіозу, є величина викривлення. Сколіоз - це не локальне захворювання, воно викликає порушення травної, сечовидільної, дихальної та серцево-судинної систем. Сколіоз також може супроводжуватися спінальними порушеннями й навіть парезами та паралічем унаслідок стиснення нервових корінців [3]. Тривалі дослідження проблеми виникнення та розвитку сколіозу показали чітку тенденцію до зростання кількості хворих із І-ІІ ступенями деформації серед студентів унаслідок впливу низки екзогенних факторів, а також великих і глибоких змін як у скелеті, так і в м'яких тканинах хребта, що пов'язані зі загальним станом організму та обміном

\section{ЛІТЕРАТУРА}

1. Аббасов Ш. К. Комплексное лечение больных сколиозом / Ш. К. Аббасов, А. Р. Сатторов // Ортопедия, травматология и протезирование. - 2003. - № 4. - С. 113-116.

2. Алексеева А. Т. Клинико-рентгенологическое и физиологическое обоснование физических упражнений у больных с начальными степенями сколиоза / А. Т. Алексеева, Ю. Н. Мороз, М. И. Мурзина // Тез. докл. - Новгород : [б. и.], 1985. - С. 154-155.

3. Бачу Г. С. Деформация позвоночника у детей и ее коррекция средствами лечебной физкультуры / Г. С. Бачу // Республ. научн.-практ. конф. : тез. докл. Орхей, 1990. - С. 91-92.

4. Бойчук Т. Оцінювання функціонального стану хребта в учнів старшого шкільного віку з порушеннями постави в сагітальній площині / Т. Бойчук, Л. Войчишин // Фізичне речовин $[1,6]$. Дослідження фізичного розвитку в студентів зі сколіозом, зокрема його фізіологічних показників, дало можливість визначити ефективність запропонованої методики консервативного лікування сколіотичної деформації із застосуванням сучасних засобів та методів. Повторне тестування, що включало оцінку фізичного стану й фізичної працездатності студентів, проводилося з метою дослідження змін цих показників у студентів зі сколіотичною хворобою після застосування програми відновного лікування.

Висновки. Сколіоз І-ІІ ступенів суттєво впливає на організм студентів, при цьому знижується рівень фізичної працездатності та фізичного стану. Як свідчить динаміка результатів фізіологічного тестування, запропонована програма відновного лікування $\epsilon$ досить ефективною в разі її застосування в цього контингенту хворих, адже показники фізичної працездатності та фізичного стану студентів значно покращилися порівняно з їх рівнем на початку дослідження.

виховання, спорт і культура здоров'я у сучасному суспільстві : зб. наук. пр. Волин. нац. ун-ту ім. Лесі Українки. Луцьк : Волин. нац. ун-т ім. Лесі Українки, 2010. - № 1 (9). С. 73-77.

5. Евминов В. Профилактор Евминова. Комплекс силових упражнений / В. Евминов. - К. : [б. и.], 2007. - 34 с.

6. Окамото Г. Основи фізичної реабілітації : навч. посіб. / Г. Окамото ; пер. з англ. Ю. Кобіва, К. А. Добриніної. - Л. : [6. в.], 2002. - 232 с.

7. Олійник І. Інноваційні технології корекції порушень постави і деформацій хребта / І. Олійник, С. Іваськів, К. Єрусалимець // Фізичне виховання, спорт і культура здоров'я у сучасному суспільстві : зб. наук. пр. Волин. нац. ун-ту ім. Лесі Українки. - Луцьк : РВВ «Вежа» Волин. нац. ун-ту ім. Лесі Українки, 2008. - Т. 3. - С. 104-107. 